\title{
THE FUNCTION PRESIDENT OF THE REPUBLIC OF MACEDONIA AND LEADING OF THE MACEDONIAN FOREIGN POLICY
}

\author{
Aneta Stojanovska-Stefanova* \& Drasko Atanasoski**
}

The latter principle of the fundamental values of the constitutional order of the Republic of Macedonia is respect of the generally accepted norms of international law. Namely, with the belonging of the international community, each state as a unitary and federal falls under the authority of the rules or standards of behavior that are built in that community. Foreign policy and international relations of each country are conditioned with its internal policy and with the basic features of the political system. Besides, the principles and objectives of the foreign policy and international relations are expression and effect of its internal politics, i.e. the basic social relations that determine the physiognomy and character of the basic political institutions, and the content and purposes of the political decisions. Chapter VI of the Constitution of the Republic of Macedonia is dedicated to the issue whereby clearly and unequivocally is indicated that, for proper functioning of the democratic state, it is important how the internal as well as the issues of the international relations are regulated.

INTRODUCTION 81

I. Personal ACCOUnts of the Former Presidents of the Republic OF MACEDONIA IN THE AREA OF FOREIGN POLICY .............................................. 84 II. CuRrent Macedonian President and His Venture IN the Foreign

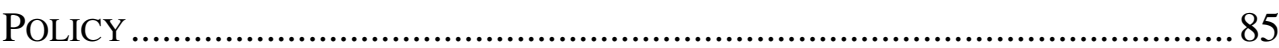

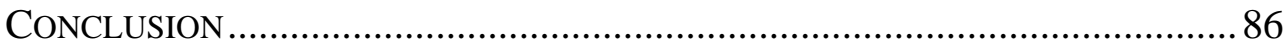

\section{INTRODUCTION}

With the Law on Foreign Affairs ${ }^{1}$ precisely are defined, the responsibilities of authorities for performing of the foreign work. With the same prescriptive in details normatively is determined, the whole process of creation, establishment and implementation of the foreign policy, as well as the relations between the authorities conducting foreign affairs and the state

\footnotetext{
* Aneta Stojanovska-Stefanova, PhD Candiudate, Teaching Assistant, Faculty of Tourism and Business Logistics, University Goce Delcev, Stip, Republic of Macedonia. Research fields: International Law and Politics, History of diplomacy, Political System.

** Drasko Atanasoski, Ph.D., assistant professor, Faculty of Tourism and Business Logistics, University Goce Delcev, Stip, Republic of Macedonia. Research fields: International Transport and Logistics, Costums Administrative Procedure.

${ }^{1}$ Law on Foreign Affairs, Official Gazette of the Republic of Macedonia 46/06.
} 
government authorities, in the exercising of the foreign affairs, which reduces the possibility of overlapping or dysfunction. Characteristic of the Law on Foreign Affairs of the Republic of Macedonia is that, besides the traditional approach towards creating such a norm, it emphasizes the role of the Assembly of the Republic of Macedonia.

Also, by the law, it is determined the jurisdiction, structure and operation of the Ministry of Foreign Affairs, which before the adoption of the law was governed by one member of its competence and the Law on the organization and operation of the state administration authorities, i.e. some members in the same law for competences of the management authorities. The great part of the matter for the essential elements of the organization and work of the Ministry before the adoption of the law were moved by-laws.

Furthermore, the law defines the diplomatic and consular representations that Republic of Macedonia can open abroad, and the procedure and conditions of appointment of the head of the diplomatic-consular office. More precisely is determined the procedure for revocation of the heads of the missions, and their duties, responsibilities and relations with the authorities for performing of the foreign works. Determined are specific duties and diplomatic-consular officers working in diplomatic-consular offices.

The Law on Foreign Affairs in Article 2, precisely determines and delimits the terms foreign affairs and foreign policy.

The term "foreign affairs" refers to actions performed by the competent authorities of the state government and the state government management in the exercise and protection of the rights and interests of the Republic of Macedonia in the international relations with the countries, international authorities, organizations and communities.

While the term "foreign policy" refers to political objectives and activities of the Republic of Macedonian relations with countries and with international authorities, organizations and communities that protects the interests of the Republic of Macedonia in the international relations and protect the interests of its citizens and the legal entities registered in it.

In determining the term head of state or President meet in more terms.

"The head of the state is the authority that represents the state in the country and abroad, namely, it represents the state unity and independence, whereupon it is not important whether it is a monarch or head of state in the country in the republican establishment, as regardless of whether it is for independent or collective body." ${ }^{2}$

\footnotetext{
${ }^{2}$ FrchKoski Lu. D., Tupurkovski V., \& Ortakovski V., InTernational Public LaW 186 (Tabernakul, Skopje 1995).
} 


\section{THE FUNCTION PRESIDENT OF THE REPUBLIC 83}

The term head of state means the authority that has significant powers, but is not a holder of the supreme, legally unlimited power, which belongs to the principle of the Constituent and/or legislative body. ${ }^{3}$

Another group of theorists define the head of state, as an individual or corporate body who embodies the political community and the long duration of the state, and performs ceremonial functions related with the representing of the country at home and abroad. ${ }^{4}$

The procedure for the election of the President of the Republic of Macedonia is regulated in the Articles 80 and 81 of the Constitution of the Republic of Macedonia ${ }^{5}$ and the Electoral Code. ${ }^{6}$

The President of the Republic of Macedonia is elected by direct and immediate elections, by secret ballot, for a period of five years. ${ }^{7}$ For President of the Republic, a same person can be elected mostly twice. The secondary election is not necessarily to proceed to the previous term, as is the case (e.g., NB) with the Constitution of Slovenia from $1991 .{ }^{8}$

The powers of the President of the Republic of Macedonia in the execution of the foreign affairs are defined in Article 5 of the Law on Foreign Affairs, according to which the President of the Republic of Macedonia: represents the country in the international relations, in accordance with the international law and its responsibilities; participates in the creation of the foreign policy in cooperation with the Government, through the establishment of general guidelines on the foreign policy, including issues of the international relations with implications on security and defense of the country; monitors the implementation of the foreign policy and the results and any disagreements with other bodies for foreign affairs performing, can inform the Assembly; gives suggestions and participates in the pose of views on some foreign-policy matters within its competence, including the security and defense aspects arising from the international relations; appoints and dismisses by decree ambassadors and representatives of the Republic of Macedonia abroad, in procedure determined by this Law; gives consent to the issuance of agreement of the head of foreign diplomatic office and accepts the credentials and revoked

\footnotetext{
${ }^{3}$ BAJALDZIEv DimitAR, InTROdUCTION IN LAW-First BoOK 92255 (Evropa 1999).

${ }^{4}$ MAKLIN IAN, Concise OXFORD's Dictionary FOR Politic 385 (Skopje: Publishing House MiAN 2002).

${ }^{5}$ Constitution of the Republic of Macedonia, Official Gazette of the Republic of Macedonia 52/91.

${ }^{6}$ Electoral Codex, Official Gazette of the Republic of Macedonia 40/06.

${ }^{7}$ Gligorov Kiro, Macedonija is Everything That We Have 160 (Skopje: Publishing House TRI 2001).

${ }^{8}$ ShKarikJ SVEtomir, Comparative AND MACEDONian Constitutional Law 619 (Matica Makedonska Skopje 2004).
} 
letters of the foreign diplomatic representatives, in the procedure established by this law ${ }^{9}$.

\section{Personal Accounts of the Former Presidents of the Republic of MACEDONIA IN THE AREA OF FoREIGN POLICY}

The President of the Republic of Macedonia, as one of the pillars of the governance, holds executive powers, which mostly are focused in the hands of the Government. The relations of the Head of State with the Government and the Assembly are intertwined. Namely, the major powers in the field of the international relations, the President of the country performs in coordination with the Government and the Assembly of the Republic of Macedonia, and also should be noted that owns means of control over them, through the right to request to attend at the parliamentary session, right to veto acts adopted by the Assembly, the right to participate in the scheduled parliamentary session, and so on.

In the mandate of the first President of the Republic of Macedonia, Kiro Gligorov formally and factually were established the foundations of the Macedonian foreign policy. President Gligorov in the formulation of foreign policy priorities of the Republic of Macedonia began from the basic conclusion, according to which in world frames even stronger swing takes the globalization and in the regional frames in the integration process. In his mandate, the President Gligorov established four key foreign policy priorities, first, the existence of the road to acquire and preserve with peaceful means the independence of the Republic of Macedonia, second, the Republic of Macedonia to become a factor and condition for stability and peace in the Balkans, and not "apple of discord", third, to reject war and violence and to promote the European idea in the Balkans and fourth, to build relationships of equality with the neighboring countries and fifth, acceptance of the principles of moderation and realism in the conduct of the foreign policy. In the relations with the neighboring countries, the President Gligorov promoted the policy of equidistance which included readiness for a good cooperation with all neighbors, because it ensures the independence, territorial integrity and peace and security in the Balkans.

The second president of the Republic of Macedonia, Boris Trajkovski, left the concept of equidistance, formulated by his predecessor, and dedicated to strengthening the relations between the Republic of Macedonia and the United States, and the establishment of relations of Macedonia's

\footnotetext{
${ }^{9}$ Aneta Stojanovska, Constitutional-Legal and Political Aspects of the Foreign Policy, with Special Retrospection to Republic of Macedonia, MASTER THESIS, 28.
} 


\section{THE FUNCTION PRESIDENT OF THE REPUBLIC 85}

integration into the European Union. The President Trajkovski considered that, the politics equidistance reflects the reservation and that this concept is indefinite, so hence he devoted himself to building internal Balkan cooperation which is complementary to the Euro-Atlantic integration. In this regard, the President Gligorov formulated the basic tenets to which he adhered to in performing the function: first, the Republic of Macedonia as a young country on its way to full integration in the international policy faces many challenges, secondly, the developmental internal and external processes require clearly defined, precise, well-coordinated and patientdriven foreign policy, third, the success in the foreign policy is closely related to the success in the internal politics, fourth the unanimity and coordination in the implementation of the foreign policy represent a condition without which is not possible, achieving the smallest purposes.

The third President of the Republic of Macedonia Branko Crvenkovski, in the part of the conducting of the foreign policy started from three basic settings, first, for further intensify and development of the relations of the Republic of Macedonia with neighboring countries, secondly, further upgrading of the strategic friendship of the Republic of Macedonia with the United States of America and third, continuing of the efforts for integration. According to the President Crvenkovski, the European Union integration of the Western Balkan countries at the same time is and the stabilization of the region, and closing of the historical chapter of mutual confrontation and conflict $^{10}$.

\section{Current Macedonian President and His Venture in the Foreign POLICY}

The fourth and current President of the Republic of Macedonia prof. Gjorge Ivanov, PhD, regarding the part of conducting of foreign policy, has established continuity of the fundamental goals of his predecessors, first, the European Union is unfinished project without the integration of the region, the Euro-Atlantic membership and policy of openness to all, the President Ivanov underlined them as leading points in the foreign-policy strategy of the country, stressing that, he will work dedicated to strengthening and deepening of the mutual trust and friendship with the countries from all over the world, especially in the economic and cultural spheres. Second aspect of the Macedonian foreign policy, which the President Ivanov has emphasized is the development of good neighborly relations and the contribution to the Macedonian stability and prosperity of the region. The third postulate to

${ }^{10}$ Ibid, at 30 . 
which the President Ivanov adheres is for firmly existence of the Republic of Macedonia in the way of regional cooperation, based on the principle of equality. President Ivanov is a leading expert in the field of civil society and among the very firsts to introduce systematic research of this area in the Macedonian academic society. He was a consultant to prominent thinktanks and research centers. Generations of leaders have passed his training in political management. Professor Ivanov is one of the co-founders of the first Macedonian political science journal "Political Thought". He is founder of the first Political Science Association in independent Macedonia. Ivanov is also one of the founders of the Institute for Democracy, Solidarity and Civil Society, a renowned Macedonian think-tank which has helped shape the political landscape in Macedonia and served as guide to many young talents in the politics. Although never a party member, Professor Gjorge Ivanov was active in designing the reform policy of the political party VMRO-DPMNE, the party that supported his presidential nomination at the 2009 elections. ${ }^{11}$

\section{CONCLUSION}

The term head of state means the authority that has significant powers, but is not a holder of the supreme, legally unlimited power, which belongs to the principle of the Constituent and/or legislative body.

The procedure for the election of the President of the Republic of Macedonia is regulated in the Articles 80 and 81 of the Constitution of the Republic of Macedonia, and the Electoral Code.

The President of the Republic of Macedonia is elected by direct and immediate elections, by secret ballot, for a period of five years. For President of the Republic, a same person can be elected mostly twice.

We could conclude that, the powers of the President of the Republic of Macedonia in the execution of the foreign affairs are defined in Article 5 of the Law on Foreign Affairs, according to which the President of the Republic of Macedonia: represents the country in the international relations, in accordance with the international law and its responsibilities; participates in the creation of the foreign policy in cooperation with the Government, gives suggestions and participates in the pose of views on some foreignpolicy matters within its competence, including the security and defense aspects arising from the international relations; appoints and dismisses by decree ambassadors and representatives of the Republic of Macedonia

\footnotetext{
${ }^{11}$ President of the Republic of Macedonia Dr. Gjorgje Ivanov, Available at http://president.mk/en/president/biography.html (last visited August 8, 2015).
} 


\section{THE FUNCTION PRESIDENT OF THE REPUBLIC 87}

abroad, in procedure determined by this Law; gives consent to the issuance of agreement of the head of foreign diplomatic office and accepts the credentials and revoked letters of the foreign diplomatic representatives, in the procedure established by the law. 